\title{
Clinical significance of intrahepatic hepatitis C virus levels in patients with chronic $\mathrm{HCV}$ infection
}

\author{
G H Haydon, L M Jarvis, C S Blair, P Simmonds, D J Harrison, K J Simpson, P C Hayes
}

\begin{abstract}
Background-The clinical significance of a single assessment of circulating hepatitis $C$ virus (HCV) RNA and its relation to the level of intrahepatic HCV RNA remains unclear.

Aims-To investigate the relation between intrahepatic HCV levels and clinicopathological characteristics of chronic $\mathrm{HCV}$ infection.

Patients-Ninety eight consecutive patients with chronic HCV infection were studied; none had received $\alpha$ interferon therapy. Of these, 12 patients were repeatedly negative for HCV RNA in serum by reverse transcriptase polymerase chain reaction (RT-PCR).
\end{abstract}

Methods-After diagnostic laparoscopy and liver biopsy, semiquantitative analysis of intrahepatic HCV RNA levels was carried out by limiting dilution of $\mathrm{HCV}$ cDNA. HCV genotypes were assessed in 96 patients by restriction fragment length polymorphism analysis of HCV cDNA.

Results-Ten out of 12 patients who were RT-PCR negative for HCV RNA in serum were RT-PCR positive in liver; however, this group had a significantly lower intrahepatic HCV level and serum aminotransferase level than the remaining 86 patients. Histological severity (cirrhosis: $\mathrm{n}=10$ ); histological activity index; $\mathrm{HCV}$ genotype (genotype 1: $n=41$; genotype 2: $n=12$; genotype $3: \mathbf{n = 3 6}$; genotype $4: n=7)$; mode of infection (intravenous drug abuse: $n=58$; post-transfusion: $n=10$; haemophiliac: $n=4$; sporadic: $n=26$ ) and alcohol abuse did not affect the intrahepatic virus level. There was no correlation between patient age, duration of infection, and intrahepatic HCV level.

Conclusions-Intrahepatic virus levels were not determined by host factors (age of patient, mode or duration of infection) or by virus factors (HCV genotype). Repeatedly negative RT-PCR for HCV RNA in serum does not indicate absence of HCV from the liver.

(Gut 1998;42:570-575)

Keywords: intrahepatic hepatitis $\mathrm{C}$ virus; chronic hepatitis $\mathrm{C}$ virus infection

Hepatitis $\mathrm{C}$ virus (HCV) is the predominant cause of post-transfusion and sporadic non-A non-B hepatitis worldwide. ${ }^{1-5}$ Approximately $95 \%$ of $\mathrm{HCV}$ infected individuals can be identified by third generation anti-HCV testing. ${ }^{67}$ However, this test does not indicate active infection, and there is considerable controversy as to the biochemical, virological, and histological definitions of a "past infection".

Initial, fundamental studies suggested that negative serum HCV cDNA polymerase chain reaction (PCR) results in recombinant immunoblot assay (RIBA) positive individuals correlated with the absence of inflammation in liver biopsy specimens. ${ }^{8}$ The serum HCV cDNA PCR result was therefore a sensitive and specific marker of liver disease in anti-HCV positive subjects, independent of serum alanine aminotransferase (ALT) values; true healthy carriers of HCV did not exist. Following these reports, it has been recommended that patients negative in serum for $\mathrm{HCV}$ cDNA do not undergo routine liver biopsy; furthermore, that those with persisting abnormal liver function tests should be screened for other liver diseases (for example, autoimmune chronic active hepatitis or haemochromatosis), while those with normal liver function tests ought to be followed up annually until the natural history of the disease is better documented. ${ }^{9}$

Many previous studies have examined the significance of serum HCV levels and have shown a wide range of clinicopathological relations ${ }^{10-18}$; however, there are fewer data examining intrahepatic HCV levels and their associations. ${ }^{19-29}$ In general, previous data have not shown any correlation between HCV levels in the liver and other demographic factors such as sex, age, duration of illness, and risk factors. There is a suggestion that some genotypes, in particular genotype $1 \mathrm{~b}$, may be associated with higher serum and liver virus levels ${ }^{30-32}$; but in contrast with serum studies, intrahepatic studies have not shown any correlation between HCV RNA levels and liver injury. ${ }^{19-29}$

To address these issues further, we determined the clinical, histological, and intrahepatic virological profile of patients with serum repeatedly negative for HCV RNA by reverse transcriptase (RT) PCR; we then compared this population with a control population of patients whose serum was repeatedly positive for HCV by RT-PCR. Concurrently, we investigated the relation between intrahepatic $\mathrm{HCV}$ levels and the clinicopathological characteristics of chronic HCV infection.

\section{Patients and methods}

PATIENTS

Ninety eight consecutive patients (69 male; mean age $37.8 \pm 8$ years) with chronic $\mathrm{HCV}$ infection were included in the study; none had received $\alpha$ interferon therapy. All patients were positive for anti-HCV antibodies by second generation enzyme immunoassay (EIA-2, 
Table 1 Comparison of demographic and virological data of serum RT-PCR positive and negative patients, all of whom have persistent infection

\begin{tabular}{|c|c|c|c|}
\hline Host or virus parameter & Serum RT-PCR negative & Serum RT-PCR positive & $p$ Value \\
\hline Age $(y)$ & $35.2(6)$ & $37.8(8)$ & NS \\
\hline $\operatorname{Sex}(M / F)$ & $7 / 3$ & $61 / 25$ & NS \\
\hline Mode of infection & $\begin{array}{l}6 \text { IVDA; } 1 \\
\text { post-transfusion; } 1 \\
\text { haemophiliac; } 2 \text { sporadic }\end{array}$ & $\begin{array}{l}51 \text { IVDA; } 9 \\
\text { post-transfusion; } 2 \\
\text { haemophiliac; } 24 \text { sporadic }\end{array}$ & NS \\
\hline $\begin{array}{l}\text { Duration of infection } \\
\text { (median (range)) }\end{array}$ & $16(8-22)$ & $12(4-42)$ & NS \\
\hline Alcohol & 2 & 13 & NS \\
\hline HIV & 0 & 3 & NS \\
\hline Hepatitis B virus & 0 & 1 & NS \\
\hline Normal ALT & 7 & 8 & $<0.001$ \\
\hline Disease state & $\begin{array}{l}1 \text { Cirrhosis; } 9 \text { chronic } \\
\text { hepatitis }\end{array}$ & $\begin{array}{l}9 \text { Cirrhosis; } 77 \text { chronic } \\
\text { hepatitis }\end{array}$ & NS \\
\hline Histological activity index & $6(1-13)$ & $8(1-14)$ & NS \\
\hline Riba- 3 bands & $\begin{array}{l}9 \text { Present (>2 bands); } 1 \\
\text { ind }\end{array}$ & - & NS \\
\hline HCV genotype & $\begin{array}{l}4 \text { Genotype } 1 ; 1 \text { genotype } \\
2 ; 4 \text { genotype } 3 ; 1 \\
\text { genotype } 4\end{array}$ & $\begin{array}{l}37 \text { Genotype } 1 ; 11 \\
\text { genotype } 2 ; 32 \text { genotype } \\
3 ; 6 \text { genotype } 4\end{array}$ & NS \\
\hline
\end{tabular}

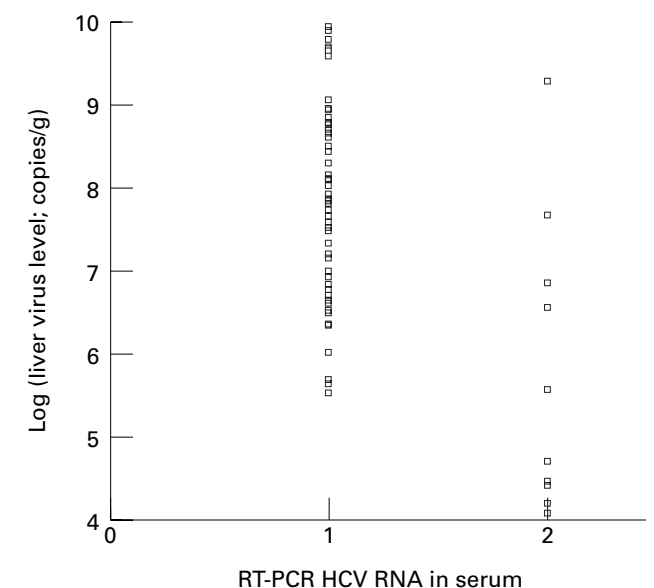

Figure 1 Intrahepatic virus levels in patients repeatedly $H C V R N A$ positive $(n=86)$ or negative $(n=12)$ by RT-PCR.

Abbot Laboratories, Weisbaden, Germany) and third generation recombinant immunoblot assay (RIBA-3, Chiron, Emeryville, California). Fifty eight patients had acquired their infection through abuse of intravenous drugs (IVDA), 10 had acquired infection from red cell concentrate transfusions, four were haemophiliacs transfused with infected blood prod-

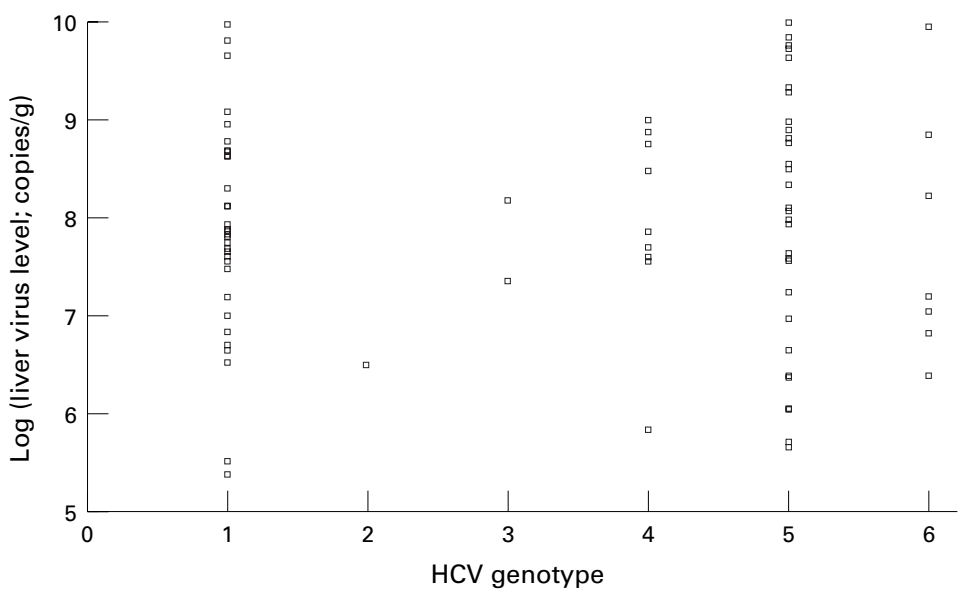

Figure 2 Intrahepatic virus levels by HCV genotype. 1, genotype 1 a $(n=40) ; 2$, genotype $1 b(n=1) ; 3$, genotype $2 a(n=2) ; 4$, genotype $2 b(n=10) ; 5$, genotype $3(n=36) ; 6$, genotype $4(n=7)$. ucts, and in 26 there were no obvious risk factors for infection.

At the time of admission to hospital, each patient was questioned about the likely duration of their infection (in the case of the IVDA group, this was calculated from the year of first injection). Serum aminotransferase was measured on the day of diagnostic laparoscopy.

A small portion of the liver biopsy specimen taken at laparoscopy was washed in ice cold normal saline, blotted on a sterile swab, and immediately frozen in liquid nitrogen and stored at $-70^{\circ} \mathrm{C}$ for future use. The remainder of the biopsy specimen was used for histological analysis.

Serum samples were obtained, separated within three hours of collection on the day of laparoscopy, and stored at $-70^{\circ} \mathrm{C}$. All samples were stored for a maximum of three to six months before analysis.

HCV RNA EXTRACTION FROM SERUM SAMPLES RNA was extracted from 0.1 or $0.5 \mathrm{ml}$ of stored serum from each of the patients as previously described. ${ }^{33}$ Briefly, the RNA was pelleted by centrifugation at $100000 \mathrm{~g}$ for 90 minutes at $4^{\circ} \mathrm{C}$ and incubation at $37^{\circ} \mathrm{C}$ for two hours with $1 \mathrm{mg} / \mathrm{ml}$ proteinase $\mathrm{K}$ in the presence of $40 \mu \mathrm{g} / \mathrm{ml}$ polyadenylic acid, $0.5 \%$ sodium dodecyl sulphate (SDS), $0.1 \mathrm{M} \mathrm{NaCl}$, $50 \mathrm{mM}$ Tris $\mathrm{HCl}$ (pH 8.0), and $1 \mathrm{mM}$ EDTA. RNA was extracted with phenol; after centrifugation, the supernatant was re-extracted successively with phenol and chloroform-isoamyl alcohol (50:1). Nucleic acid was precipitated by the addition of one tenth volume of sodium acetate ( $\mathrm{pH}$ 5.2) and two volumes of ethanol. The dried pellet was resuspended in $25 \mu \mathrm{l}$ of diethyl pyrocarbonate treated water.

HCV RNA EXTRACTION FROM LIVER BIOPSY SAMPLES

RNA extraction from liver biopsy samples was carried out using a commercial modification (RNAzol, Biogenesis Ltd, Bournemouth, UK) of the single step method of RNA isolation by acid guanidinium thiocyanate-phenol-chloroform extraction. ${ }^{34}$

Tissue samples were homogenised with RNAzol solution (phenol derivative); RNA was extracted by centrifugation at $12000 \mathrm{~g}$ for 15 minutes at $4^{\circ} \mathrm{C}$ with chloroform. RNA was precipitated by addition of isopropanol to the aqueous phase; the samples were stored for 15 minutes at $4^{\circ} \mathrm{C}$ and then centrifuged for 15 minutes at $12000 \mathrm{~g}\left(4^{\circ} \mathrm{C}\right)$; the RNA precipitates formed a white-yellow pellet at the bottom of the tube. The supernatant was removed, and the RNA pellet was washed once with $75 \%$ ethanol by vortexing and centrifuged for eight minutes at $7500 \mathrm{~g}\left(4^{\circ} \mathrm{C}\right)$. The dried pellet was resuspended in $25 \mu \mathrm{l}$ diethylpyrocarbonate treated water.

RT-PCR AND VIRAL GENOTYPING

RNA was reverse transcribed and amplified using nested primers matching the 5 '-NCR. ${ }^{34}$ Product DNAs were cleaved with restriction enzymes Hae-111/Rsa-1 and Mva-1/Hinf-1. ${ }^{35-39}$ The fragments were 
Table 2 Correlation coefficients between intrahepatic virus levels and patient age, duration of infection, serum aminotransferase level, and histological activity index

\begin{tabular}{llll}
\hline Parameter & $\begin{array}{l}\text { Population median } \\
\text { (range) }\end{array}$ & $\begin{array}{l}\text { Pearson correlation } \\
\text { coefficient }\end{array}$ & p Value \\
\hline Age (y) & $37(24-65)$ & 0.0624 & 0.55 \\
Serum aminotransferase & $72(13-577)$ & 0.091 & 0.391 \\
Duration of infection (y) & $12(4-42)$ & -0.0661 & 0.592 \\
Histological activity index & $8(1-14)$ & 0.082 & 0.47 \\
\hline
\end{tabular}

separated by agarose gel electrophoresis using 4\% Metaphor agarose (FMC BioProducts). Phylogenetic comparisons of sequences in the conserved region of the genome confirm that 5'-NCR can be used to distinguish the six major genotypes. ${ }^{38}$

QUANTITATION OF HCV LEVELS IN SERUM

SAMPLES AND LIVER TISSUE

Liver tissue samples were quantified by limiting dilution of cDNA reverse transcribed from HCV RNA. This has been described in detail elsewhere. ${ }^{40}{ }^{41}$ Briefly, $5 \mu \mathrm{l}$ of HCV cDNA was diluted in a series (five for serum samples and seven for liver biopsy samples) of 10-fold steps which allowed cDNA to be quantified to within $1 \log$ of its actual concentration. Further refinement of the quantitation by adding a specific volume of cDNA to a number of replicate PCR reactions, thus giving a Poisson distribution of positive and negative samples, and allowing the exact $\mathrm{HCV}$ concentration to be determined, has been shown not to be necessary to improve the accuracy of the assay if the nearest whole log only is required.

Positive controls $\left(4 \times 10^{5}\right.$ copies $\left./ \mathrm{ml}\right)$ were run concurrently with each limiting dilution analysis to ensure reproducibility of the assay. Serum samples from healthy individuals without risk factors were examined for HCV RNA as negative controls.

The previously established efficiency of 5\% for the reverse transcription reaction was assumed in this assay. Centrifugation of $0.1 \mathrm{ml}$ serum provided a detection sensitivity of approximately $4000 \mathrm{HCV}$ copies $/ \mathrm{ml}$. To increase the sensitivity of the PCR method, samples that were negative at this level of detection (less than $4000 \mathrm{HCV} / \mathrm{ml}$ ) were further analysed by centrifugation of $0.5 \mathrm{ml}$ (detection sensitivity: $800 \mathrm{HCV}$ copies $/ \mathrm{ml}$ ) or if necessary $5.0 \mathrm{ml}$ (detection sensitivity: $80 \mathrm{HCV}$ copies/ $\mathrm{ml}$ ) of serum.

The limiting dilution assay has been shown to have significant reproducibility when multiple samples are tested in duplicate, using RNA

Table 3 Qualitative histological findings and alanine aminotransferase (ALT) and intrahepatic HCV levels in serum RT-PCR HCV RNA negative patients with persistent hepatic infection

\begin{tabular}{|c|c|c|c|c|c|c|}
\hline Patient no & $A L T(U / l)$ & $\begin{array}{l}\text { Log liver } \\
\text { virus level } \\
\text { (copies/g) }\end{array}$ & Steatosis & $\begin{array}{l}\text { Portal } \\
\text { inflammation }\end{array}$ & $\begin{array}{l}\text { Lobular } \\
\text { information }\end{array}$ & $\begin{array}{l}\text { Periportal } \\
\text { fibrosis }\end{array}$ \\
\hline 1 & 37 & 4.72 & - & + & + & - \\
\hline 2 & 11 & 5.42 & - & - & + & - \\
\hline 3 & 69 & 4.10 & - & + & + & + \\
\hline 4 & 32 & 6.57 & - & + & + & - \\
\hline 5 & 35 & 7.68 & - & + & + & + \\
\hline 6 & 37 & 4.44 & - & + & + & + \\
\hline 7 & 56 & 9.28 & - & + & + & + \\
\hline 8 & 40 & 4.49 & - & - & + & - \\
\hline 9 & 105 & 4.22 & - & + & + & + \\
\hline 10 & 19 & 5.58 & & - & + & + \\
\hline
\end{tabular}

extracted on separate days from separate aliquots of sample and different batches of reagents. Likewise a significant correlation has been shown between limiting dilution and three commercial assays: bDNA1, bDNA2 (Chiron, Emeryville, California), and Roche Monitor. Furthermore, when the quantity of transcripts of genotypes 1, 2, and 3 was compared by limiting dilution, there was a statistically similar distribution of the quantity of virus. This indicates that no correction factor for different genotypes $(1,2$, and 3$)$ is required when using this assay for quantitating hepatitis C virus levels. ${ }^{42}$

HISTOLOGICAL ANALYSIS

Liver biopsy specimens from all 98 patients were available for assessment by a single observer blinded to the clinical and serological data. Histological features were graded according to the classifications of Knodell et $a l^{43}$ assessing portal, periportal, and lobular inflammation as well as fibrosis.

STATISTICAL ANALYSIS

The results were analysed by non-parametric tests where appropriate: the $\chi^{2}$ or Fisher's exact test, the Mann-Whitney test, or Kruskal-Wallis probability tests.

\section{Results}

During an eighteen month period, intrahepatic HCV levels of 12 patients repeatedly negative for HCV RNA in serum by RT-PCR (on three separate occasions) were assessed and compared with 86 patients repeatedly positive for HCV RNA in serum by RT-PCR.

The relation between intrahepatic HCV levels and the clinicopathological characteristics of chronic HCV infection was then investigated.

\section{VIRUS FACTORS}

\section{Serum RT-PCR for HCV RNA}

Ten out of 12 patients RT-PCR negative for HCV RNA in serum were RT-PCR positive in the liver; however, this group had both a significantly lower intrahepatic HCV level $(p<0.0001)$ (fig 1) and a significantly lower serum aminotransferase level $(p<0.001)$ (table 1) than the remaining 86 patients. Table 1 illustrates the demographic and virological similarity between the serum RT-PCR negative and positive patients. There was no significant correlation between virus levels and any parameter.

\section{HCV genotype}

Hepatitis C virus genotypes were assessed in 96 patients by restriction fragment length polymorphism analysis of $\mathrm{HCV}$ cDNA. There was no significant difference in intrahepatic virus levels between patients infected with genotype $1(n=41)$, genotype $2(n=12)$, genotype 3 $(\mathrm{n}=36)$, and genotype $4(\mathrm{n}=7)$ (fig 2$)$. The two patients who were RT-PCR negative in both liver and serum could not be genotyped.

LIVER HISTOLOGY

Ten patients had cirrhosis at diagnostic laparoscopy and liver biopsy. The remaining 88 


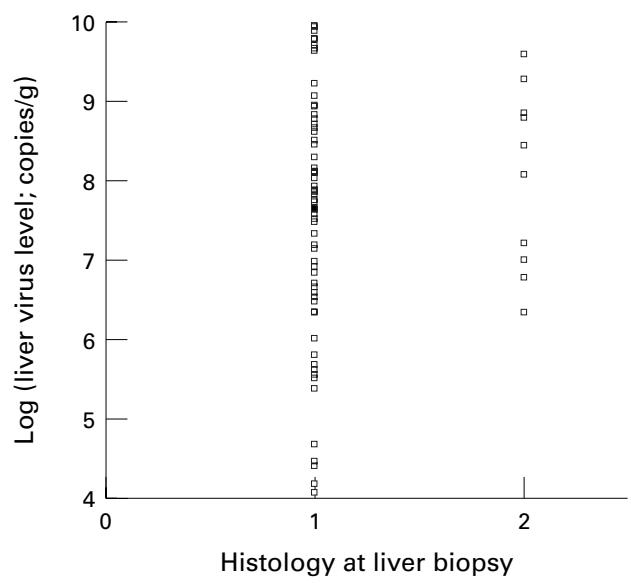

Figure 3 Intrahepatic virus levels by disease state. 1, Chronic hepatitis; 2, cirrhosis.

patients had macroscopic and histological features of ongoing inflammatory activity in keeping with chronic HCV hepatitis. Neither the histological severity nor the histological activity index (HAI) affected the intrahepatic virus levels (fig 3; table 2).

Table 3 illustrates the descriptive histological findings in the 10 patients who were serum RT-PCR negative for HCV RNA, but RT-PCR positive in the liver.

PATIENT FACTORS

Mode and duration of infection

Intrahepatic HCV levels were unaffected by either the mode or duration of infection (fig 4; table 2).

\section{Serum aminotransferase}

There was no significant correlation between serum ALT and intrahepatic HCV levels (table 2).

\section{Cofactors}

Coinfection with hepatitis B virus (HBV) or human immunodeficiency virus (HIV), or alcohol abuse did not significantly affect intrahepatic HCV levels.

\section{Discussion}

The current pandemic of hepatitis C infection has affected $1-2 \%$ of the world's population,

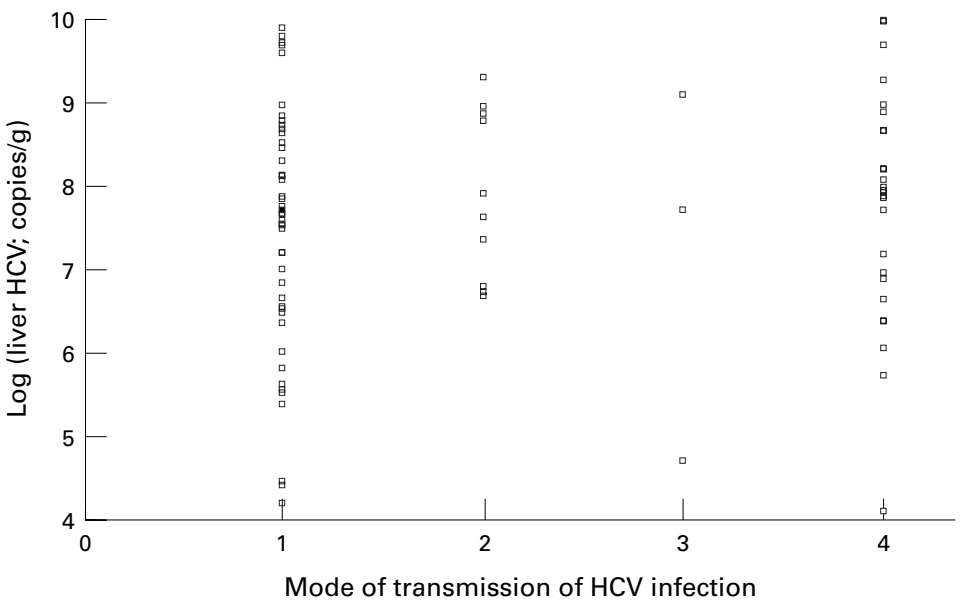

Figure 4 Intrahepatic virus levels according to mode of transmission of HCV. 1, IVDA $(n=58) ; 2$, post-transfusion $(n=10) ; 3$, haemophiliac $(n=4) ; 4$, sporadic $(n=26)$. and $0.02 \%$ of the population of the UK. ${ }^{44}$ However, it is unclear what proportion of patients have a self limiting illness, successfully eliminate $\mathrm{HCV}$, and then become immune to reinfection; furthermore, the host or virus factors increasing the likelihood of successful elimination, and the baseline markers of this process are unknown. The prognostic significance of individual clinical, epidemiological, and virological parameters in this context has also not been clarified. For these reasons, we assessed the clinical, histological, and virological profile of 98 consecutive patients, presenting for staging of their liver disease by diagnostic laparoscopy and liver biopsy and further compared a unique serum HCV cDNA PCR negative population of 12 patients with a larger subpopulation of HCV cDNA PCR positive patients. Our data have shown that repeatedly negative RT-PCR for HCV RNA did not indicate complete hepatic elimination of $\mathrm{HCV}$ in 10 out of $12(87.5 \%)$ of our patients; also that intrahepatic HCV levels were not determined by either host factors (age of patient, mode or duration of infection, concurrent alcohol abuse, or concurrent HBV/HIV infection) or by virus factors (HCV genotype).

For confirmation of positive anti-HCV test results, recombinant immunoblot assays were developed; RIBA-3 results are interpreted as "positive" when one or more bands are positive, and "indeterminate" when only one band is positive. A high proportion (75-80\%) of RIBA-3 positive patients have viraemia as detected by RT-PCR for HCV RNA. It has been suggested that RIBA-3 positive but RT-PCR negative patients may have cleared the virus from the circulation after a previous infection, may be viraemic below the RT-PCR detection level, or may represent false positive anti-HCV reactivity. Previous studies have indicated that RT-PCR negative/anti-HCV positive patients correlate with absence of inflammation on liver biopsy specimens, and this observation probably indicates clearance of the virus. ${ }^{45}$ In our study 10 out of 12 (87.5\%) patients were RT-PCR positive for HCV RNA in liver tissue, but RT-PCR negative in serum and all had ongoing inflammation diagnosed at diagnostic laparoscopy and liver biopsy. This favours the hypothesis that these patients were viraemic below the RT-PCR detection level in serum (in our case, this was a detection sensitivity of $800 \mathrm{HCV}$ copies $/ \mathrm{ml}$ in $0.5 \mathrm{ml}$ of serum); furthermore, patients RT-PCR positive for HCV RNA in serum had a significantly higher intrahepatic HCV level than patients RT-PCR negative for HCV RNA in serum. Remarkably, comparison of the serum RTPCR negative and positive subpopulations indicated that they were statistically similar in terms of demographic, histological, and virological data; the serum RT-PCR negative subpopulation did however have a significantly lower serum ALT than the RT-PCR positive patients despite the poor correlation between liver virus level and ALT overall. Possibly, the serum RT-PCR negative patients, with their concurrent lower intrahepatic HCV level and ALT, may have a lower grade hepatic 
inflammation; however, there is no significant difference in HAI between the populations. Therefore, the prognostic importance of these data is that serum RT-PCR negative patients with chronic HCV infection should be followed up indefinitely, and at present there is no indication that they are at a lower risk of severe liver disease in the future. We propose follow up studies assessing these patients for the presence of very low levels of viraemia by increasing the detection sensitivity to 80 copies $\mathrm{HCV} / \mathrm{ml}$ in 5 $\mathrm{ml}$ of serum or even eight copies $\mathrm{HCV} / \mathrm{ml}$ in 50 $\mathrm{ml}$ of serum.

The second important finding of this report was the absence of a significant relation between host or virus factors and intrahepatic HCV levels; thus the significance of a single assessment of intrahepatic HCV RNA in terms of diagnosis and prognosis remains unclear. Indeed, in contrast with similar serum studies, this finding corresponds to previous intrahepatic studies which have shown no correlation between HCV RNA levels and liver injury. ${ }^{19-29}$ The largest of these studies utilised three different methodologies for quantitation of HCV RNA (Dot-Blot PRC, end point titration, and Roche Amplicor Monitor Assay), examined interassay and intra-assay variability in detail, and showed no significant association with the degree of liver injury. ${ }^{29}$ There are at present no data measuring viral replication in addition to the total HCV load and its effect on liver injury. Recently, new techniques have been developed to overcome the methodological problems associated with detection of true replicative (negative or antisense) HCV RNA levels, but their ability to quantitate specifically HCV RNA over a wide range of HCV levels is still limited. ${ }^{46} 47$

There was no correlation in our study between HCV RNA levels in liver and other demographic factors such as sex, age, duration of illness, and mode of infection. These data confirm previous studies on liver virus levels but contrast with studies examining serum levels of HCV RNA where increased levels have been shown in relation to age, sex, mode, and duration of infection. ${ }^{10-18}$ This observed discrepancy may be explained by a combination of factors: contribution to serum HCV RNA levels from virus in other tissues (and from necrotic liver tissue), HCV RNA in serum immune complexes, technical variation between methods, different populations studied, and time dependent fluctuation in serum $\mathrm{HCV}$ levels. Certainly analysis based on serum studies is more difficult to interpret than that based on intrahepatic studies.

In addition, we did not show an effect of HCV genotype on intrahepatic virus levels. This conflicts with data indicating that genotype $1 \mathrm{~b}$ generally has higher HCV RNA levels in serum and liver and therefore a higher viraemic load than other genotypes tested. ${ }^{30-32}$ However, genotypic analysis of our data was limited by the presence of only one patient infected with genotype $1 \mathrm{~b}$, while 19 patients were infected with genotype $1 \mathrm{a}$.

In conclusion, we have successfully shown that repeatedly negative RT-PCR for $\mathrm{HCV}$
RNA in serum does not indicate complete hepatic elimination of HCV. Indeed, these patients have a similar clinical, pathological, and epidemiological profile to serum RT-PCR positive patients; their prognosis and requirements for full staging of liver disease are thus likely to be similar, and further follow up is mandatory. However, we were unable to show any significant associations between intrahepatic HCV levels and other clinicopathological parameters. Importantly, these data support the hypothesis that HCV does not cause liver disease by a cytopathic process; they also illustrate the limitations of a single assessment of $\mathrm{HCV}$ levels. Clearly, there is a requirement for sequential studies of chronic HCV infection in terms of molecular virological and clinical parameters, before the clinical significance of intrahepatic HCV levels is established.

1 Choo QL, Kuo G, Weiner AJ, et al. Isolation of a cDNA clone derived from a blood-borne non-A, non-B viral clone derived from a blood-b

2 Kuo G, Choo Q-L, Alter HJ, et al. An assay for circulating antibodies to a major etiological virus of human non-A, non-B hepatitis. Science 1989;244:362.

3 Kato N, Hijikata M, Ootsuyama Y, et al. Molecular cloning of the human hepatitis $\mathrm{C}$ virus genome from Japanese patients with non-A, non-B hepatitis. Proc Natl Acad Sci 1990;87:9524-8.

4 Alter HJ, Purcell RH, Shih JW. Detection of antibody to hepatitis $\mathrm{C}$ virus in prospectively followed transfusion recipients with acute and chronic liver disease. N Eng $\mathcal{F} \mathrm{Med}$ 1989;2:1494-500.

5 Esteban JI, Esteban R, Viladomiu I, et al. Hepatitis C antibodies amongst risk groups in Spain. Lancet 1989;ii: 294-8.

6 Courouce AM, Bouchardeau F, Girault A. Significance of NS3 and Ns5 antigens in screening for HCV antibody. Lancet 1994;343:853-4.

7 Bousch MP, Tobler LH, Francis BS. Re-instatement of blood donors who test false-positive in second generation hepatitis $\mathrm{C}$ virus enzyme immunoassay should await availability of licensed third-generation tests. Transfusion 1994; 34:130-4.

8 Alberti A, Morsica G, Chemello L, et al. Hepatitis C viraemia and liver disease in symptom free individuals with antiHCV. Lancet 1992;340:697-8.

9 Booth JCL, Brown JL, Thomas HC. The management of chronic hepatitis C infection. Gut 1995;37:449-54.

10 Kato N, Yokosuka O, Hosoda K, et al. Quantification of hepatitis C virus by competitive reverse transcription polymerase chain reaction: increase of the virus in advanced liver disease. Hepatology 1993;18:16-20.

11 Yuki N, Hayashi N, Kamada T. HCV viraemia and liver injury in symptom free blood donors [letter]. Lancet 1993; 342:444.

$12 \mathrm{Hu} \mathrm{KQ}$, Yu CH, Vierling JM. Direct detection of circulating hepatitis C virus RNA using probes from the 5 untranslated region. f Clin Invest 1992;89:2040-5.

13 Lau JY, Davis GL, Kniffen J, et al. Significance of serum hepatitis C virus RNA levels in chronic hepatitis C. Lancet 1993;341:1501-4.

14 Gunji T, Kato N, Mori S, et al. Correlation between the serum level of hepatitis $\mathrm{C}$ virus RNA and disease activities in acute and chronic hepatitis C. Int $\mathcal{F}$ Cancer 1992;52:72630 .

15 Kaneko S, Murakami S, Unoura M, et al. Quantification of hepatitis $\mathrm{C}$ virus RNA by competitive polymerase chain reaction. F Med Virol 1992;37:278-82.

16 Kobayashi Y, Watanabe S, Konishi M, et al. Quantification and typing of serum hepatitis $C$ virus RNA in patients with chronic hepatitis $\mathrm{C}$ treated with interferon-beta. Hepatology 1993;18:1319-25.

17 Chayama K, Tsubota A, Arase Y, et al. Quantitative analysis of hepatitis $\mathrm{C}$ virus RNA by competitive nested polymerase chian reaction. f Gastroenterol Hepatol 1993;8:S40-4.

18 Jeffers L, Dailey P, Coelholittle E, et al. Correlation of HCV RNA quantitation in sera and liver tissue of patients with chronic C hepatitis [abstract]. Gastroenterology 1993;104: A923.

19 Sakamoto N, Enomoto N, Kurosaki M, et al. Dectection and quantification of hepatitis $C$ virus RNA replication in the liver. F Hepatol 1994;20:593-7.

20 Nakagawa H, Shimomura H, Hasui T, et al. Quantitative detection of hepatitis $\mathrm{C}$ virus genome in liver tissue and circulation by competitive reverse transcription polymerase chain reaction. Dig Dis Sci 1994;39:225-33.

21 Fong TL, Shindo M, Feinstone SM, et al. Dectection of replicative intermediates of hepatitis $\mathrm{C}$ viral RNA in liver and serum of patients with chronic hepatitis C. F Clin Invest 1991;88:1058-60. 
22 Lau G, Fang J, Davis G, Gish R, et al. Detection of hepatitis C (HCV) genome in liver by in-situ reverse transcription (IS-RT-PCR) [abstract].

23 Nouri-Aria KT, Sallie R, Sanger D, et al. Detection of genomic and intermediate replicative strands of hepatitis C
virus in liver by in-situ hybridization. $\mathcal{F}$ Clin Invest 1993;91: virus in liver

24 Haruna Y, Hayashi N, Hiramatsu N, et al. Detection of hepatitis C virus RNA in liver tissues by an in-situ hybridization technique. $\mathcal{F}$ Hepatol 1993;18:96-100.

25 Marrone A, Kleiner D, Mahaney K, et al. The significance of hepatic HCV RNA: analysis by semi-quantitative in-situ hybridisation. Hepatology 1994;20:236A.

26 Di-Bisceglie AM, Hoofnagle JH, Krawczynski K. Changes in hepatitis $\mathrm{C}$ virus antigen in liver with antiviral therapy. Gastroenterology 1993;105:858-62.

27 Hiramatsu N, Hayashi N, Haruna Y, et al. Immunohistochemical detection of hepatitis $\mathrm{C}$ virus-infected hepatocytes in chronic liver disease with monoclonal antibodies to cytes in chronic liver disease with monoclonal antibodies to core, envelope and NS3 regions of
genome. Hepatology 1992;16:306-11.

28 Blight K, Rowland R, Hall PD, et al. Immunohistochemical detection of the NS4 antigen of hepatitis C virus and its relationship to histopathology. Am F Pathol 1993;143:1568 73.

29 McGuiness PH, Bishop GA, Painter DM, et al. Intrahepatic hepatitis C RNA levels do not correlate with degree of liver injury in patients with chronic hepatitis C. Hepatology 1996;23:676-87.

30 Lau JY, Mizokami M, Kolberg KA, et al. Application of six hepatitis $\mathrm{C}$ genotyping systems to sera from chronic hepatitis C patients in the United States. F Infect Dis 1995;171: 281-9.

31 Yamada $M$, Kakumu S, Yohioka K, et al. Hepatitis C virus genotypes are not responsible for development of serious liver disease. Dig Dis Sci 1994;39:234-9.

32 Hayashi J, Kihihara Y, Yoshimura E, et al. Relationship of genotype to level of hepatitis C viraemia determined by
competitive polymerase chain reaction. $\mathcal{F}$ Infect $1995 ; 30$ : 235-9.

33 Jarvis LM, Watson HG, McOmish F, et al. Frequent reinfection and reactivation of hepatitis $\mathrm{C}$ virus genotypes in multitransfused haemophiliacs. F Infect Dis 1994;170:1018.

34 Chomczynski P, Sacchi N. Single-step method of RNA isolation by acid guanidinium thiocyanate-phenol-chloroform extraction. Anal Biochem 1987;162:156-9.

35 Chan SW, McOmish F, Holmes EC, et al. Analysis of a new hepatitis $\mathrm{C}$ virus type and its phylogenetic relationship to existing variants. $\mathcal{F}$ Gen Virol 1992;73:1131.
36 Nakao T, Enomoto N, Takada N, et al. Typinf of hepatitis C virus (HCV) genomes by restriction fragment polymorphisms. F Gen Virol 1991;72:2105-12.

37 McOmish F, Chan S-W, Dow BC, et al. Detection of three types of hepatitis $\mathrm{C}$ virus in blood donors: investigation of type-specific differences in serological reactivity and rate of alanine aminotransferase abnormalities. Transfusion 1993; 33:7-13.

38 McOmish F, Yap PL, Dow BC, et al. Geographical distribution of hepatitis $\mathrm{C}$ virus genotypes in blood donors-an international collaborative survey. F Clin Microbiol 1994;31: 884-92.

39 Simmonds P, Smith DB, McOmish F, et al. Identification of genotypes of hepatitis $\mathrm{C}$ virus by sequence analysis comparisons in the core, E1 and NS-5 regions. 7 Gen Virol 1994;75:1053-61.

40 Simmonds P, Balfe P, Peutherer JF, et al. Human immnuodeficiency virus-infected individuals contain provirus in small numbers of peripheral mononuclear cells and at low copy numbers. F Virol 1990;64:864-72.

41 Simmonds P, Zhang LQ, Watson HG, et al. Hepatitis C quantification and sequencing in blood products, haemophiliacs, and drug users. Lancet 1990;336:1469-72.

42 Hawkins A, Davidson F, Simmonds P. Comparison of plasma virus loads among individuals infected with hepatitis $C$ virus (HCV) genotypes 1,2 and 3 by quantiplax HCV RNA assay versions 1 and 2 , Roche Monitor assay, and an RNA assay versions 1 and 2, Roche Monitor assay, and an
in-house dilution method. $\mathcal{F}$ Clin Microbiol 1997;35:187-

43 Knodell RG, Ishak KG, Black WC, et al. Formulation and application of a numerical scoring system for assessing histological activity in asymptomatic chronic active hepatitis. Hepatology 1981;1:431-5.

44 Irving WL, Neal KR, Underwood JCE, et al. Chronic hepatitis in United Kingdom blood donors infected with hepatitis C virus. Lancet 1994;308:695-6.

45 Alberti A, Morsica G, Chemello L, et al. Hepatitis C virae$\mathrm{mia}$ and liver disease in symptom free individuals with antiHCV. Lancet 1992;340:697-8.

46 Gunji T, Kato N, Hijikata $M$, et al. Specific detection of positive and negative stranded hepatitis $\mathrm{C}$ viral RNA using chemical RNA modification. Arch Virol 1994;134:293-302.

47 Lanford RE, Sureau C, Jacob JR, et al. Demonstration of in vitro infection of chimpanzee hepatocytes with hepatitis $C$ virus using strand specific RT/PCR. Virology 1994;202: $606-14$ 